\title{
Risk and benefit judgment of excreta as fertilizer in agriculture: An exploratory investigation in Rwanda and Uganda
}

\author{
Nelson Ekane ${ }^{a}$, C. K. Mertz ${ }^{b}$, Paul Slovic ${ }^{c}$, Marianne Kjellén ${ }^{d}$, and Hans Westlund ${ }^{e}$ \\ ${ }^{a}$ Royal Institute of Technology and Stockholm Environment Institute, Stockholm, Sweden; ${ }^{\mathrm{b}}$ Decision Research, \\ Eugene, OR, USA; 'Decision Research and University of Oregon, Eugene, OR, USA; ${ }^{\mathrm{d}}$ Stockholm International

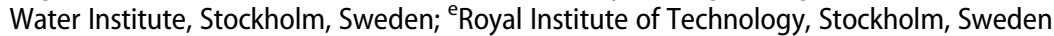

\begin{abstract}
This research explores the use of psychometric techniques to improve understanding of psychological mechanisms underlying judgment of excreta as fertilizer in agriculture including other excreta-related activities. Participants consisted of environmental health students, smallholder farmers, and traders in rural and urban Rwanda and Uganda. The finding reveals an inverse relationship between risk and benefit judgments. This relationship holds for the three groups of participants with significant risk and benefit correlations of $p<.0001$. This finding is consistent with other studies in showing that affect plays a key role in risk perception, judgment, and decision-making. Building on this finding, we conclude that individuals with high risk and low benefit judgment for excreta-related practices would eschew them or emphasize strict standards. Individuals with a high benefit and low risk judgment would engage in excreta management practices regardless of the actual risks involved. This finding is relevant for risk communication and risk management as it indicates that individuals do not rely only on risk management information they receive concerning excreta and related risks but also depend, to an extent, on their feelings about these substances when making judgments and decisions regarding the purpose for using excreta as fertilizer and the level of exposure they can tolerate and manage.
\end{abstract}

\section{ARTICLE HISTORY}

Received 6 May 2015

Revised manuscript accepted

22 September 2015

\section{KEYWORDS}

excreta; fertilizer; affect; risk; benefit; judgment

\section{Introduction}

\section{Background}

Recirculation of nutrients in human wastes, mainly excreta (faeces and urine) has prevailed since time immemorial within some communities in different parts of the world, particularly in South East Asia (King 1927; also see Rockefeller 1998; Mackie Jensen et al. 2005, 2008; Phuc et al. 2006; Pham-Duc et al. 2014). In communities where this practice is commonplace, it is characterized largely by unsafe collection of mostly faecal sludge from different types of latrine pits and septic tanks and application of this sludge, usually untreated, directly

CONTACT Nelson Ekane nelson.ekane@abe.kth.se, nelson.ekane@sei-international.org (KTH), Urban and Regional Studies (URS), Dröttning Kristinas väg 30, SE-100 44 Stockholm, Sweden Royal Institute of Technology 
to agricultural land and fish ponds (Cofie et al. 2005; Phuc et al. 2006; Knudsen et al. 2008; Mackie Jensen et al. 2008; Pham-Duc et al. 2011, 2014).

In spite of recent development in knowledge, capacity, and best practices for using human excreta and even wastewater for different purposes in closed loop systems, mainly "toilet to farm" and "toilet to tap" systems, respectively (WHO 2006a,b), a number of challenges remain in introducing and mainstreaming these systems as well as in transforming ongoing unsafe excreta and wastewater related practices. Two major challenges include: first, resistance to these closed loop systems within many communities and among many individuals partly due to perceived public health risks (Rozin et al. 2015); and second and ironically, risky or unsafe excreta and wastewater related practices prevail in some communities where the productive use of human excreta and wastewater is common-place (Cofie et al. 2005; Phuc et al. 2006; Mackie Jensen et al. 2008; Knudsen et al. 2008; Karg and Drechsel 2011; Pham-Duc et al. 2014).

Drawing from the field of psychology, this article addresses the former challenge, while still highlighting related aspects of the latter challenge. The article further attempts to explain why most individuals are unwilling to engage in the productive use of human wastes whereas some do. A deeper understanding of these challenges is important for targeted risk communication between stakeholders-public health personnel, sanitary inspectors, agricultural extension workers, policymakers, farmers, traders, and the rest of the community. Renn (2008) stresses that a good understanding of psychological processes may provide useful insights for risk communication which takes into account judgments or decisions reflecting best available knowledge and preferences.

Unlike with human excreta and wastewater, the use of animal excreta, whether treated (through for example composting) or untreated, in agriculture is generally regarded with much less resistance and hence is a relatively less sensitive issue and a widespread practice. Even the use of wastewater in agriculture and aquaculture is perceived as relatively less sensitive than the use of human excreta for same purposes. For instance, Knudsen et al. (2008) report that the public health problems associated with wastewater use especially in aquaculture are perceived by farmers in Nghe An province, Vietnam to be less severe than those associated with the use of human excreta for similar purpose.

In this article, we explore the psychological mechanisms underlying perceptions and judgment of practices and technologies involving specifically the use of treated and untreated excreta as fertilizer in agriculture ("toilet to farm" systems). To understand why the use of human excreta as fertilizer for food crop production in particular evokes repugnance in many individuals, we need to examine how the nature and characteristics of these substances shape perception and drive judgment and decision-making regarding their productive use.

This article is structured as follows: first, we briefly discuss the nature and characteristics of human excreta and show how these shape perception and drive judgment and decisionmaking. We also examine risk perception and the role it plays in judgment and decisionmaking. Then, we introduce the conceptual frame and theoretical background and justify their relevance in examining the challenges this article addresses. Next, we discuss the potential risks and benefits of human wastes as resource and review related risk and benefit tradeoffs from previous studies. Last, we report findings from empirical investigation of risk and benefit judgments and discuss the implications for risk management and risk communication. 


\section{Contagion, disgust, and pathogen sensitivity}

Much has been written on contagion, disgust or the feeling of revulsion and pathogen sensitivity as explanatory factors for avoidance of physical contact with substances such as human excreta, which are potential sources of pathogens that can contaminate and cause harm (de Barra 2011; Curtis 2013; Tybur et al. 2013; Callaghan et al. 2012; Rozin et al. 2015). Rozin et al. (2015) describe contagion as "once in contact, always in contact," which means that when two entities come into contact, they exchange properties or "essences." Regarding human excreta and wastewater, these "essences" manifest as odor, color, and diseases. The smell and appearance of human excreta in their untreated form are highly repugnant, which is an instinctive mechanism deterring humans from getting into direct contact with them. Even discussions surrounding human excreta and their use as fertilizer for food crop production in particular are unpleasant to many people.

De Barra (2011) and Curtis (2013, p. 9) categorize human wastes including excreta as hygiene disgust elicitors intended to prevent humans from contamination by pathogens. Tybur et al. (2013) emphasize that disgust plays a key role in motivating human behavior that probabilistically reduces exposure to pathogens. They argue that human faeces and other bodily fluids are some of the main substances that people across cultures find intuitively disgusting and consider as infectious disease threat or risk factors.

What remains one of the most pertinent issues regarding the productive use of human excreta is that the aversive feeling towards these substances persists for most individuals even after the substances have been safely treated and transformed into resources that are appealing in appearance and odor. Rozin et al. (2015) report that public resistance to the use of treated wastewater, particularly for drinking ("toilet to tap" systems) has its roots largely in psychology. This also applies to "toilet to farm" systems.

\section{Risk perception and judgment of human excreta and their use as fertilizer}

From a risk perception point of view, "dread," "unknown," and "uncertainty" have been identified as some of the factors determining the type and magnitude of risk people can tolerate. "Dread" refers to potentially catastrophic, uncontrollable and involuntary characteristics of risk, whereas "unknown" is an unfamiliar characteristic of risk (Bickerstaff 2004; Meng et al. 2013; Frewer 2004; SCU 2014). Furthermore, Sjöberg et al. (2004, p. 7) argue that "uncertainty" is closely related to risk and in many theories of behavior, psychological uncertainty is assumed to be an important mediator of human responses in situations with unknown outcomes.

With regard to human waste, Rockefeller (1998) emphasizes that the "unknown" and "unpredictable" characteristics of human excreta causes uncertainty in the risk of using them as fertilizer. Viau et al. (2011) also stress a number of uncertainties related to public health risks associated with spreading of treated sewage sludge (biosolids) on agricultural land: namely, aspects related to: diversity of pathogen content in sewage sludge; physiological state of pathogens in biosolids and air; susceptibility of human populations; understanding of how exposure changes with movement of people and contaminants; and data used in biosolids risk assessment.

Smith et al. (2011) posit that risk perception plays a prominent role in the judgments and decisions people make. According to Renn and Rohrmann (2000), risk perception is 
a complex product of social, cultural, political, emotional, and intuitive factors. Pertaining to the type and nature of risk we are referring to in this article, Slovic (2010) distinguishes between three fundamental types of risk that humans depend on for guidance: "risk as a feeling," which refers to fast, instinctive, and intuitive reactions to danger ("fast system"); "risk as analysis," which involves logic, reason, and scientific deliberation to bear on hazard management ("slow system"); and "risk as politics," which becomes evident when our ancient instincts and modern scientific analysis clash. Each of these dimensions of risk is useful in explaining different psychological mechanisms or processes of human behavior, judgment and decision-making under different circumstances. However, Zajonc (1980) and Murphy and Zajonc (1993) argue that all perceptions contain some affect and affective reactions to stimulus are often the very first reactions, occurring automatically and subsequently guiding information processing and judgment. This emphasizes the importance of the "risk as a feeling" perspective that has not been the major focus of judgment and decision-making research (Finucane et al. 2000, 2003, p. 329).

Notwithstanding, there is increasing recognition of the importance of affective processes and the need to understand exactly the role they play in driving judgment and decisionmaking (Finucane et al. 2000; Slovic et al. 2002a,b; Peters et al. 2006; also see Sparrow 2008; Kahneman 2011; WDR 2015). Peters et al. (2006) argue that in some circumstances relying on affective impressions can be simpler and more efficient than using deliberative processes, especially when the required judgment or decision is complex or mental resources are limited.

Marris et al. (1998) distinguishes between two distinct approaches for explaining risk perception: the psychometric paradigm proposed by psychologists (Slovic et al. 1985) and cultural theory proposed by anthropologists and sociologists (Douglas and Wildavsky 1982; Thompson et al. 1990). In our exploratory investigation of "risk as a feeling," we draw on the theoretical framework from the field of psychology, specifically the psychometric paradigm. The psychometric paradigm has been the dominant theoretical framework for analyzing individual risk perception within the field of psychology for a number of decades. This paradigm differs from the cultural theory or societal approach of risk in that it focuses mainly on the individual as the main target of analysis. In psychology, risk perception is argued to exist in the experiencer's mind. Hence, psychometric risk characteristics are subjective (Slovic 1992).

\section{The role of affect in judgment and decision-making processes}

In this article, we focus mainly on "risk as a feeling," and explore the assertion that affect plays a key role in judgment and decision-making (Zajonc 1980; Damasio et al. 1991; Shafir et al. 1993; Damasio 1994; Slovic 2000a,b, 2010; Finucane et al. 2000, 2003; Svenson 2003). Affect is defined as the specific quality of "goodness" or "badness" experienced as a feeling state (consciously or not) and demarcating a positive or negative quality of a stimulus (Slovic et al. 2002a, p. 397).

The affect heuristic is based on experiential thinking that is speedy, relying on emotional images and narratives that help people estimate risks and benefits intuitively (Slovic 2000b; Slovic et al. 2002b). According to Slovic et al. (2004), all images in a person's mind are marked to varying degrees with affect, and it is this "affect pool" that people consult when asked to make certain judgments or decisions. This is based on the premise that affect marks 
images (Damasio 1994), which in turn motivates human behavior (Epstein 1994, p. 710). For instance, human excreta, faeces in particular are marked with a powerful negative image in the human mind that perhaps triggers strong affective or emotional feelings guiding judgment, decision-making, and behavior, especially regarding their use as fertilizer for food crop production.

In psychology, psychometric methods are used to study human emotions or affect. Psychometric techniques are considered to be suited for identifying similarities and differences among groups of different backgrounds with regards to risk perception and attitudes. As part of this method, people are often asked to judge the current riskiness (or safety) of diverse sets of hazardous activities, practices, substances and technologies (Slovic 2000a). The psychometric paradigm is based on the premise that feelings elicited by an event or stimulus, for example, human excreta as explored in this study have an impact on judgments and decisions people make (Finucane et al. 2000; Slovic et al. 2002a,b).

\section{Inverse relationship between perceived risk and perceived benefit}

Alhakami and Slovic (1994), and Finucane et al. (2000) found that risk and benefit are negatively related in peoples' minds even though they are positively correlated in the environment. They argue that the reason for this is that an affective feeling is referred to when the risks and benefits of specific hazards are judged. For instance, if an activity such as the use of human or animal excreta in agriculture is "liked" or "desirable," people may judge their risks as low and their benefits as high and vice versa if the activity is "disliked" or "dreaded." Giving that human excreta are averted and abhorred due to the negative emotion evoked by them, activities related to them are good stimuli for investigating the role of affect in individual judgment and decision-making.

For the purpose of risk communication, Renn (2008) emphasizes the importance of addressing the issue of how to communicate the complex picture of risk and benefit to stakeholder groups and the public at large. To do this, we need to have an understanding of the perception of these stakeholder groups and the public. Personal experience can be very important in perception of the level of risk (Eiser et al. 2012; also see SCU 2014). Also, Bostrom (1997) argues that individuals from different backgrounds use what they know to interpret information and make judgments.

\section{The context}

Public resistance to the use of human excreta in agriculture is generally discernible in most parts of the world, including regions with poor soil quality and water scarcity. This is the situation in most developing parts of the world, sub-Sahara Africa (SSA) being no exception, where there is also a great need to improve soil quality and food security. Giving that the availability and use of chemical fertilizers in SSA remain relatively low (Yamano and Arai 2010) partly due to poverty related factors and the unprecedented rise in chemical fertilizer prices in recent years, smallholder farmers continue to depend largely on a variety of locally available natural options to meet their needs. The most commonly used agricultural inputs include crop residues, green manure, and animal manure. Human faeces and urine are not fully exploited. 
This investigation was performed in Rwanda and Uganda, which are two neighboring and landlocked countries in Central and East Africa, respectively, highly dependent on agriculture and having predominantly rural smallholder farming populations.

Moreover, the sanitation and hygiene conditions in both countries are largely inadequate and dysfunctional, and as a result, sanitation and hygiene related diseases are widespread. Dysfunctional and inadequate sanitation and hygiene is estimated to cost Rwanda and Uganda some USD 54 million/year and USD 177 million/year, respectively. The greatest proportion of this cost is as a result of premature death due to diarrheal diseases (WSP 2012). Traditional pit toilets are the predominant type of sanitation solution in both countries (Morella et al. 2008).

People in both countries use a variety of agricultural inputs including treated and untreated human faeces and urine, which are used mainly by some individuals on a variety of food crops.

\section{From waste to resource: Excreta as fertilizer in agriculture}

\section{Potential risks and benefits of using excreta as fertilizer in agriculture}

The use of human excreta in agriculture presents both benefits and risks (WHO 1989, 2006a,b; Mackie Jensen et al. 2008; Pham-Duc et al. 2014). Human faeces and urine are known to be rich in organic matter and nutrients respectively (Höglund et al. 1999; Kärrman et al. 1999; Schouw et al. 2002; Heinonen-Tanski and van Wijk-Sijbesma 2005; also see Polprasert 2007). When properly and safely managed in closed loop systems, human faeces and urine have the potential to improve soil quality by adding organic matter and nutrients to the soil to boost crop productivity. Such benefits are particularly evident among smallholder farming populations in rural and peri-urban settings where the production, distribution, and application of manure to farm is a vital part of smallholder arable farming.

However, the hygiene and safety aspects of practices involving the use of human faeces and urine in agriculture are not always appropriate (Cofie et al. 2005; Knudsen et al. 2008; Pham-Duc et al. 2014). When closed loop systems are poorly introduced and managed, they pose severe threat to human and environmental health and may potentially exacerbate the situation in areas where water and hygiene are inadequate and basic sanitation facilities are dysfunctional such as in the countries where this study is conducted. Cofie et al. (2005) report that in spite of the problems of foul smell and health issues such as itching and foot rot that smallholder farmers in Tamale, Ghana suffer from as they collect, handle and spread faecal sludge on agricultural land, a large number of them still carry on with the practice. Phuc et al. (2006), Knudsen et al. (2008), and Mackie Jensen et al. (2008) report that smallholder farmers in Vietnam and China perceive human excreta as a valuable resource in boosting agricultural productivity regardless of the potential health risks. Pham-Duc et al. (2014) also conclude that the use of faecal sludge in agriculture remains widespread in Northern and Central Vietnam even though professional exposure to faecal sludge during agricultural activities significantly contributes to the risk of diarrheal diseases in adults.

There are various kinds of enteric microorganisms present in human and animal excreta, many of which are pathogenic. The most prevalent types of enteric pathogens in excreta, mainly in faeces include bacteria, viruses, and parasites (protozoa and helminths) (Jones and Martin 2003). Even though human urine is sterile and often perceived to be safe to handle 
and use as Magid et al. (2006) report, Heinonen-Tanski and van Wijk-Sijbesma (2005) warn that parasitic germs such as helminth eggs or schistosoma miracadia may find their way into the soil through the urine of infected persons or through urine contaminated by faeces.

In spite of the relatively relaxed perception towards animal manure and their use as fertilizer, their pathogenic content and associated health risks are also significant and worth highlighting. Pell (1997) reports that cow manure is a heterogeneous substrate consisting not only of faeces and urine but also of secretions from the nose, throat, vagina, blood, mammary gland, skin, and placenta as well as carbon-rich bedding material (straw, saw dust, etc.) or milking center waste or flush water. Köpke et al. (2007) add that animals may shed pathogens through excreta without showing any clinical signs of being infected. Therefore, animals and their manure are also potential sources of disease transmission to human beings (Polprasert 2007). Zhang (2011) stresses the need to address the research gap on community exposure and health impact from animal manure management. Bartram (2012) raises the issue regarding the lack of consideration of potential hazards in mixed wastes (human and animal excreta) in the World Health Organization (WHO) guidelines, and argues that there are no substantive efforts targeting animal waste specifically.

People also express fear regarding heavy metals and other chemicals in pharmaceuticals and detergents that end up in waste streams. These substances can potentially bio-accumulate in the soil when faecal sludge and animal manure, for example, are spread on farm land (see Rockefeller 1998). This is, however, an issue of relatively greater concern in developed parts of the world where there is greater use of drugs and detergents and an increasing public resistance to the use of biosolids from centralized systems in agriculture. Regarding public health risks of applying biosolids to agricultural land, Viau et al. (2011) report that airborne exposure to pathogens associated with this practice is also one of the major risks.

Regarding human excreta in particular, the public health risks and disease burden associated with poor management of excreta and unsafe hygiene practices are well reported (Feachem 1983; Esrey et al. 1985, 1991; Curtis et al. 1995; Esrey and Habicht 1986; WHO 1989, 2006a,b; Prüss et al. 2002; Kosek et al. 2003). Efforts have been made during the past few decades to improve hygiene and safety practices and waste treatment techniques. WHO recommends guidelines for safe collection, handling, treatment, and use of human excreta and wastewater in agriculture and aquaculture, and emphasize the multibarrier approach for pathogen reduction and/or removal. These guidelines are intended to promote safety and protect the health of people engaged in such practices and the public at large (WHO 1989, 2006a,b). Also, a systems approach commonly referred to as ecological sanitation (ecosan) or more recently as productive sanitation is recommended. This involves-as one methodsource separation of faeces and urine using urine diversion dry toilets (UDDTs), proper treatment of separated faeces and urine (e.g., through composting), safe application to farm or disposal, and safe food preparation before consumption (Esrey et al. 1998; Rosemarin et al. 2008). Magid et al. (2006) report the general interest among smallholder organic farmers in Hillerød, Denmark in the use of human urine for food production and the use of treated faecal sludge and biosolids for non-food production. They, however, add that some farmers are hesitant to use faecal sludge and biosolids from urban areas as fertilizer and emphasize proper handling and treatment of such wastes to maintain good organic farming standards.

Despite the promotion of these safety guidelines, multibarrier and systems approaches through different kinds of sanitation and behavior change campaigns, the collection and application of treated and untreated human faeces and urine to farm without proper hygiene 
and safety measures remains a common practice in some communities. For instance, Ekane et al. (2012) report that the use of protective equipment for handling, transporting, and applying excreta to farm is not a common practice among members of a productive sanitation cooperative in the Burera district in Northern Rwanda. Pham-Duc et al. (2014) identified handling practices of human and animal excreta as fertilizer, absence of protective measures when working with human and animal excreta, poor personal hygiene, and unsafe food and water consumption as factors contributing to the incidence of diarrheal diseases among adults in the Hanam province in Vietnam. Knudsen et al. (2008) also observed that farmers in Nghe An province in Vietnam did not follow protective measures in handling faecal matter especially when the odor emanating from them was inoffensive. These poor excreta management practices have been shown to contribute to the high prevalence of excreta transmitted infections among the population in Northern and Central Vietnam where the use of human excreta in agriculture and aquaculture is an age-old practice (van der Hoek et al. 2003; Verle et al. 2003; Phuc et al. 2006; Knudsen et al. 2008).

From a psychological point of view, there is a research gap regarding the mechanism underlying perceptions and judgment of human excreta and their use as fertilizer in agriculture. Such investigations may provide useful insights into reasons why some people in countries like Ghana, Vietnam, and China continue to collect, handle and spread faecal sludge on their farms in an unsafe manner whereas others in countries like Denmark emphasize proper risk management.

\section{Methods}

\section{Survey instrument}

We employed the expressed preference method following Fischhoff et al. (1978) and Slovic (2000a) to elicit quantitative judgments of risk and benefit of different practices, technologies and agricultural inputs. The expressed preference method uses questionnaires to measure individual judgments of risk and benefit of different practices or technologies.

\section{Study design}

\section{Risk and benefit perception survey}

Participants. We targeted individuals from different backgrounds as participants in this investigation: namely, environmental health students (EHSs), smallholder farmers (SHFs) or rural producers who depend mainly on family labor and for whom farming is the principal source of income, and traders (Ts) involved in sales of small inexpensive items. We assume that EHSs have the theoretical background in microbial risk assessment, exposure pathways, the value of faeces and urine as fertilizer, and the importance of treatment methods such as composting. On the other hand, SHFs and Ts may lack certain theoretical information about risk management techniques and hazards but certainly have their own basic and practical ways of conceptualizing risks and benefits related to farming practices and sales of farm produce. These selected groups have distinct roles in society and hence have different experiences and perceptions (Bostrom 1997; Eiser et al. 2012; also see SCU 2014). 
We administered survey questionnaires to female and male individuals of different ages (see Appendix A1) in different rural and urban settings in Rwanda and Uganda between July 2011 and November 2013. Using non-probabilistic sampling methods, we selected two separate groups of samples. One group consisted of people using UDDTs and pit latrines, including people applying a variety of agricultural inputs to different food crops on their farms. This group was predominantly made up of SHFs and some Ts. The other group consisted entirely of university students with a background in environmental health sciences.

Sample size. In Rwanda, the group of SHFs were 123 people (rural sample) and EHSs were 98 (urban sample) making a total of 221 participants. In Uganda, SHFs were 81 (rural sample), Ts were 59 (urban sample), and EHSs were 47 (urban sample) making a total of 187 participants (see Table 1). Participants were randomly assigned to one of two conditions, one judging only benefits and the other judging only risks (Fischhoff et al. 1978). Because it is known that people confound risks and benefits in their minds, using one as the cue for the other (in an inverse way) (Alhakami and Slovic 1994; Finucane et al. 2000), we felt it was better to separate these judgments by assigning respondents to separate risk and benefit groups. The marked difference in number of EHSs in the Rwanda benefit group $(n=66)$ and risk group $(n=32)$ is because a good number of EHSs in the risk group dropped out of the exercise. Ts were not part of the samples in Rwanda.

Study sites. The selected rural study sites include: Gafumba, Cyahi, and Karangara cells in Burera district, Rwanda, and Kitumba sub-county and Katuna town council in Kabale district, Uganda. These sites were selected because they share similar characteristics. A good number of the inhabitants engage in smallholder farming practices wherein human faeces and urine are used in combination with animal manure and chemical fertilizers. People using UDDTs in both rural sites have organized themselves into ecosan groups and cooperatives to promote and manage the use of human excreta in agriculture. The rural samples consisted mainly of SHFs using a variety of agricultural inputs, including human excreta.

The urban samples consisted of a mixture of mainly EHSs and some Ts. EHSs were from three different universities, one in Rwanda (Kibuye) and two in Uganda (Mbarara and Kampala). Ts were from Bwaise and Kibe zone, urban slums in Kampala city.

Survey procedure. The survey questionnaire consisted of instructions and a list of 45 items to be judged. These items included different excreta related practices and sanitation technologies outlined in a systems perspective, including different animal manure and chemical fertilizers

Table 1. Survey sample: Environmental health students, smallholder farmers, and traders in Rwanda and Uganda.

\begin{tabular}{|c|c|c|c|c|c|c|}
\hline \multicolumn{7}{|c|}{ Sample size by country } \\
\hline & \multicolumn{3}{|c|}{ Rwanda } & \multicolumn{3}{|c|}{ Uganda } \\
\hline & Benefit & Risk & Total & Benefit & Risk & Total \\
\hline Environmental health students & 66 & 32 & 98 & 22 & 25 & 47 \\
\hline Smallholder farmers & 58 & 65 & 123 & 43 & 38 & 81 \\
\hline Traders & 0 & 0 & 0 & 30 & 29 & 59 \\
\hline Total & 124 & 97 & 221 & 95 & 92 & 187 \\
\hline
\end{tabular}


(see survey questionnaire in the Appendix A2). As a guide to both the benefit and risk groups of participants, examples of benefits and risks were included in the respective questionnaires. For instance, benefits could be: improved hygiene, health and safety, increased crop yield, sales of agricultural produce, savings (e.g., time and money saved), comfort, and convenience. Risks could include exposure of users of technologies, children, workers, farmers, sellers, consumers to disease causing pathogens and other chemical contaminants when dealing with human excreta and other agricultural inputs. Risks could also include social stigma associated with certain activities.

The questionnaire was translated to local languages where appropriate and pretested. Each participant received a questionnaire and was informed that the task may not be easy and would take some time to complete. The survey exercise was organized in small group sessions of at least 15 participants per session. Each session ran for at least three hours and was facilitated by the principal investigator of this research and local research assistants with good skills in the local languages.

Rating scale. Following the instructions in the questionnaire, participants judging benefits were asked to carefully study each item in the list of items individually and think of the gross benefits accruing from each item over a period of about a year. Similarly, participants judging risks were asked to think of the total risks per year accruing from each item. After carefully going through the list of items, both groups of participants were asked to individually assign numerical benefit or risk values by giving rating of 10 to the least beneficial or risky and scaling the other ratings accordingly (e.g., 10 for least beneficial or risky and 300 for most beneficial or risky) (Fischhoff et al. 1978).

\section{Results}

\section{Risk and benefit judgments}

\section{Data analysis}

In Rwanda, only four participants (1.8\%) had any outlier responses (1 EHS and 3 SHFs). Of participants, $98 \%$ had no outliers in the Rwanda dataset. In Uganda, 14 people, 3 EHSs and 11 SHFs and Ts had some outliers; this was $7.5 \%$ of the Uganda sample. Thus, $92.5 \%$ had no outlier data in Uganda. Since the number of outliers or out-of-range data was low overall, this data was winsorized. Low outliers (responses 1 to 9) were winsorized to 10. Responses over 300 were winsorized to 300 . Winsorizing is a way of adjusting/limiting extreme values in the data to reduce the effects of possible spurious outliers. Outliers can affect the normal distribution of the data in ways that are spurious. Furthermore, to use the participants' absolute rating could lead to skewed or spurious results. Thus, each person's responses were standardized within their set of 45 responses. The ratings for each participant were standardized around a mean score of 0 with a standard deviation of 1 . This standardization maintains the relative relationship between items for each participant.

Standardized medians of all the items across participants were used in the analysis (see Appendix A3). The risk and benefit median values for all participants in both Rwanda and Uganda were combined and plotted separately for EHSs, SHFs, and Ts as shown in Figures 1, 2, and 3, respectively. 


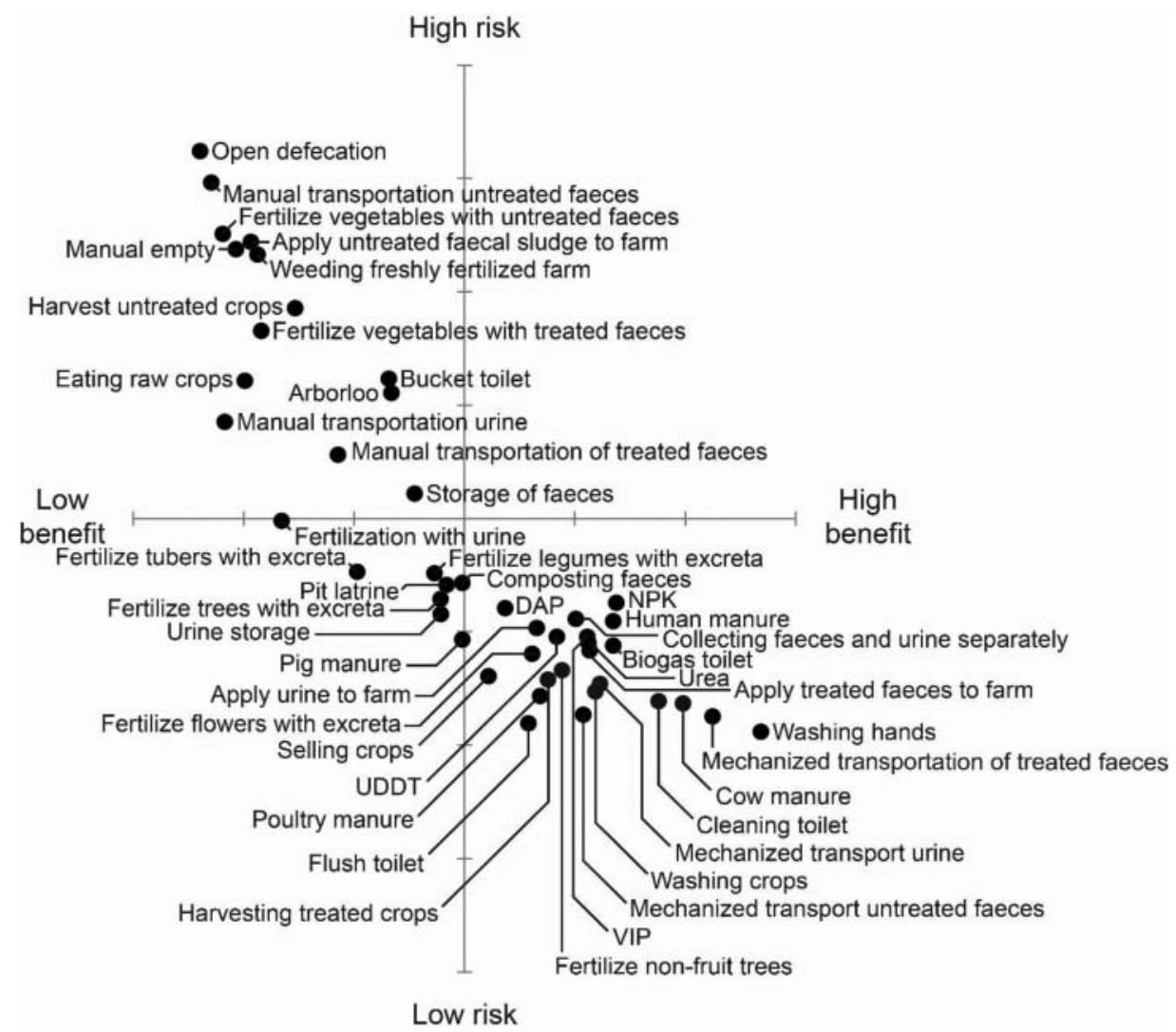

Figure 1. Combined risk and benefit judgment of environmental health students (EHSs).

From the risk and benefit judgment of EHSs (Figure 1), we see that practices and technologies are scattered mostly in the top left quadrant and the bottom right quadrant of the figure, clearly indicating an inverse relationship between the risk and benefit judgments. The majority of these practices and technologies are within the bottom right quadrant, which shows that most of the practices and technologies were judged high in benefits. As expected, practices and technologies that may involve direct contact with untreated human excreta are within the high risk low benefit quadrant. Open defecation stands out as the most risky practice. Regarding the use of human excreta as fertilizer, we see that fertilization of leafy vegetables with untreated faeces, application of untreated sewage sludge to farm, harvesting crops fertilized with untreated excreta, weeding farm fertilized with untreated excreta, and eating raw crops fertilized with excreta are all judged highly risky. Even the use of treated faeces to fertilize leafy vegetables was judged high in risk.

Practices and technologies at the bottom right quadrant have been judged high in benefit and low in risk. Washing hands with soap after using toilet and handling human excreta stands out as the most beneficial practice. We also see the preference among EHSs for practices such as mechanized transportation of treated human faeces, urine, and untreated human faeces. Regarding the use of human excreta as fertilizer, we see a preference for safe practices such as washing crops fertilized with human excreta; application of treated human faeces to farm; harvesting crops fertilized with treated human excreta; collecting human urine and 


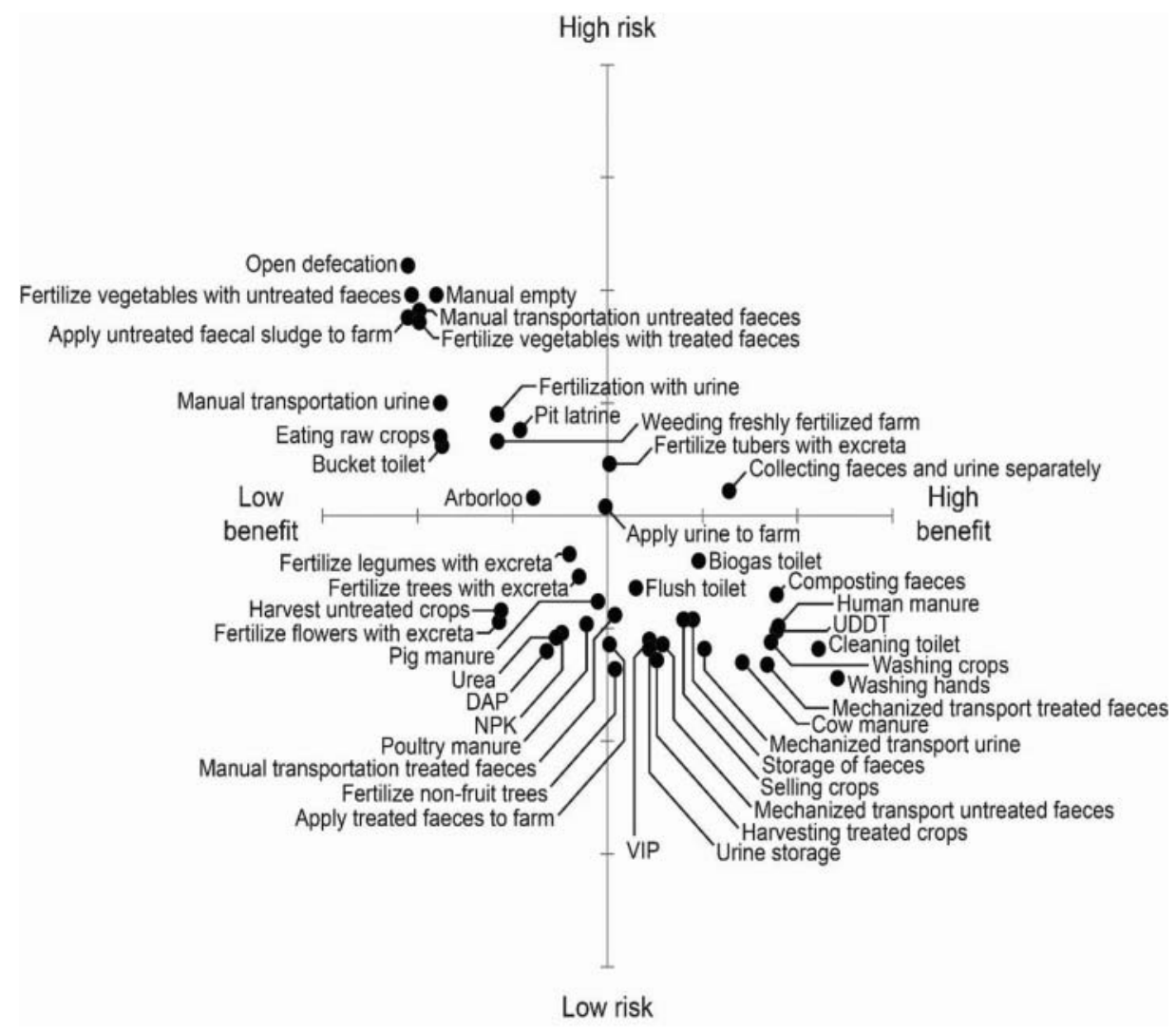

Figure 2. Combined risk and benefit judgment of smallholder farmers (SHFs).

faeces separately; fertilizing nonfruit trees and flowers with human excreta; and application of human urine to farm. Regarding the toilet technologies, biogas toilet, ventilated improved pit latrine (VIP), UDDT, and flush toilets are judged high in benefits. Cow manure appears as the most preferred type of animal manure, and considered even more beneficial than human manure. Also, all the chemical inputs were judged high in benefit with NPK being highest in benefits. Regarding UDDTs and pit latrines, which are common in the rural study sites, we see a preference for UDDT rather than for pit latrine.

As can be seen in Figure 2, the inverse relationship between judged risk and benefit also holds for SHFs. The majority of practices and technologies are clustered at the high benefit low risk quadrant indicating that they are judged high in benefit and low in risk. This figure shares a number of similarities with Figure 1. Open defecation is judged highest in risk while washing hands with soap is judged highest in benefit. Practices involving untreated excreta fall within the high risk low benefit quadrant. We also observe a preference for proper hygiene practices as well as practices involving treated excreta. Human manure is judged higher in benefit than all other types of animal manures. UDDT, biogas toilet, and flush toilet are judged high in benefit.

Figure 3 also reveals an inverse relationship between risk and benefit judgment. Unlike with the other two figures, the majority of the practices and technologies in this figure are within the high risk low benefit quadrant. Similar to the other two figures, we see 


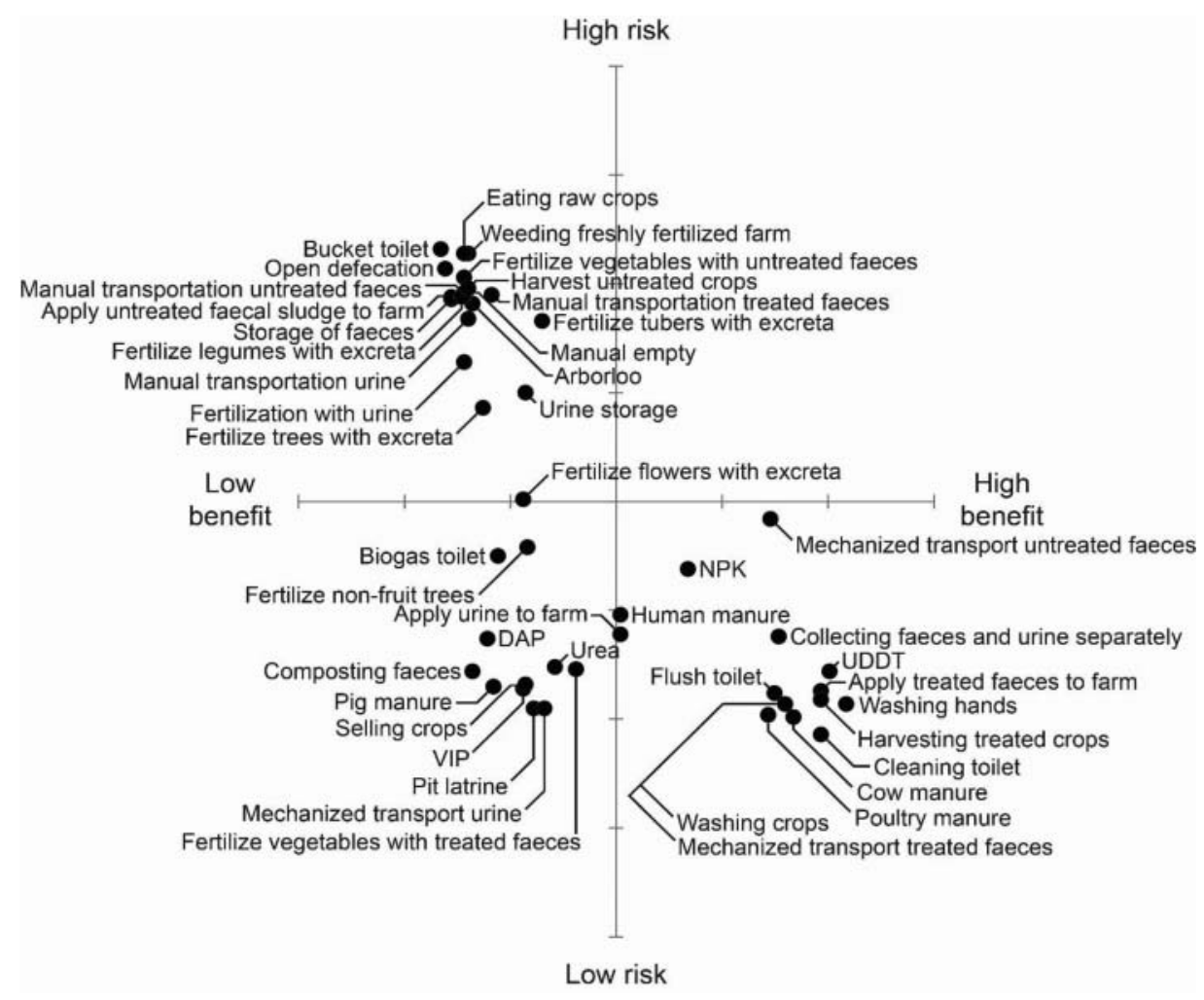

Figure 3. Combined risk and benefit judgment of traders (Ts).

a preference for proper hygiene practices as well as practices involving treated excreta. Ts prefer cow and poultry manure to human manure. UDDT and flush toilet technologies are judged high in benefit and low in risk.

\section{Tests}

Wilcoxon-Mann-Whitney median test was used to test for significant differences between the EHSs, SHFs, and Ts. To avoid some significant differences that occur by chance, we adopted more stringent criteria in determining significant differences between these groups. Tables 2, 3, and 4 show items where there are significant differences between the three groups of participants. The asterisks in these tables note where there are significant differences between the groups. This denotes a significance level of $p<.01$ (i.e., differences between the group have only a $1 \%$ probability of occurring by chance alone).

Table 2 shows the significant differences between the risk and benefit judgment of EHSs and SHFs. The risk judgment of EHSs is higher than that of SHFs for some unsafe practices such as open defecation, fertilization of leafy vegetables with untreated faeces, manual transportation of untreated faeces, application of faecal sludge to farm, and weeding farm fertilized with untreated faeces and urine.

EHSs' benefit judgment for cow dung, poultry manure, and different types of chemical fertilizers is higher than that of SHFs. EHSs also have a significantly higher benefit judgment for safe practices such as application of treated faeces to farm and fertilization of flowers 
Table 2. Difference in risk and benefit judgment between smallholder farmers (SHFs) and environmental health students (EHSs).

\begin{tabular}{|c|c|c|c|c|c|c|c|}
\hline \multicolumn{4}{|c|}{ SHFs and EHSs: Risk } & \multicolumn{4}{|c|}{ SHFs and EHSs: Benefit } \\
\hline Items & $\begin{array}{c}\text { SHFs } \\
(n=103)\end{array}$ & $\begin{array}{c}\text { EHSs } \\
(n=57)\end{array}$ & SL & Items & $\begin{array}{c}\text { SHFs } \\
(\mathrm{n}=101)\end{array}$ & $\begin{array}{c}\text { EHSs } \\
(n=88)\end{array}$ & SL \\
\hline Open defecation & 1.11 & 1.62 & $* * *$ & Composting of faeces & 0.89 & -0.01 & *** \\
\hline $\begin{array}{l}\text { Fertilization of leafy } \\
\text { vegetables } w / \\
\text { untreated faeces }\end{array}$ & 0.98 & 1.26 & $* * *$ & $\begin{array}{l}\text { Using cow dung as } \\
\text { fertilizer }\end{array}$ & 0.71 & 0.99 & $* *$ \\
\hline $\begin{array}{l}\text { Manual transportation } \\
\text { of untreated faeces }\end{array}$ & 0.91 & 1.48 & $* * *$ & Storage of human faeces & 0.45 & -0.23 & $* *$ \\
\hline $\begin{array}{l}\text { Application of faecal } \\
\text { sludge to farm }\end{array}$ & 0.88 & 1.22 & $* * *$ & $\begin{array}{l}\text { Manual transportation of } \\
\text { treated faeces }\end{array}$ & 0.04 & -0.57 & $*$ \\
\hline $\begin{array}{l}\text { Weeding farm fertilized } \\
\text { w/untreated faeces/ } \\
\text { urine }\end{array}$ & 0.33 & 1.16 & $* * *$ & $\begin{array}{l}\text { Application of treated } \\
\text { faeces to farm }\end{array}$ & 0.01 & 0.57 & $* *$ \\
\hline Bucket toilet & 0.31 & 0.62 & * & $\begin{array}{l}\text { Using poultry manure as } \\
\text { fertilizer }\end{array}$ & -0.11 & 0.34 & * \\
\hline Flush toilet & -0.32 & -0.90 & $* * *$ & Using NPK fertilizer & -0.24 & 0.69 & $* * *$ \\
\hline $\begin{array}{l}\text { Harvesting crops } \\
\text { fertilized with } \\
\text { untreated excreta }\end{array}$ & -0.42 & 0.93 & $* * *$ & Using Urea fertilizer & -0.27 & 0.56 & $* * *$ \\
\hline $\begin{array}{l}\text { Using poultry manure as } \\
\text { fertilizer }\end{array}$ & -0.48 & -0.78 & * & Using DAP fertilizer & -0.32 & 0.18 & *** \\
\hline $\begin{array}{l}\text { Ventilated improved pit } \\
\text { latrine }\end{array}$ & -0.55 & -0.86 & $* *$ & $\begin{array}{l}\text { Fertilization of flowers } \\
\text { with excreta }\end{array}$ & -0.57 & 0.31 & *** \\
\hline $\begin{array}{l}\text { Mechanized } \\
\text { transportation of } \\
\text { treated faeces }\end{array}$ & -0.66 & -0.87 & * & $\begin{array}{l}\text { Weeding farm fertilized } \\
\text { w/untreated faeces/ } \\
\text { urine }\end{array}$ & -0.58 & -0.94 & $*$ \\
\hline \multirow{4}{*}{$\begin{array}{l}\text { Washing hands w/soap } \\
\text { after using toilet/ } \\
\text { handling excreta }\end{array}$} & -0.72 & -0.94 & $*$ & $\begin{array}{l}\text { Manual transportation of } \\
\text { urine }\end{array}$ & -0.88 & -1.09 & *** \\
\hline & & & & $\begin{array}{c}\text { Manually emptying pit } \\
\text { toilet \& septic tank }\end{array}$ & -0.90 & -1.04 & $*$ \\
\hline & & & & $\begin{array}{l}\text { Manual transportation } \\
\text { of untreated faeces }\end{array}$ & -0.99 & -1.15 & $*$ \\
\hline & & & & Open defecation & -1.05 & -1.20 & $*$ \\
\hline
\end{tabular}

Values in this table are standardized medians. The Wilcoxon-Mann-Whitney Median Test is used for significance testing between groups or categories of respondents.

$\mathrm{SL}=$ Significance level: ${ }^{*} p<.01,{ }^{* *} p<.001,{ }^{* * *} p<.0001$.

with excreta. Manual emptying and transportation of treated and untreated excreta are judged low in benefit by EHSs.

Table 3 shows the significant differences in risk and benefit judgment between SHFs and Ts. As can be seen from this table, there are higher risk judgments by SHFs for practices such as fertilization of leafy vegetables with treated faeces, weeding farm fertilized with untreated excreta, cleaning toilet, eating raw crops fertilized with human excreta. We also observe a lower risk judgment by SHFs for relatively safe practices such as manual transportation of treated faeces, application of treated faeces to farm, storage of human faeces and urine, mechanized transportation of urine. Fertilization of leguminous plants with human excreta is also judged lower in risk by SHFs. Ts, however, have a significantly higher risk judgment for harvesting crops fertilized with untreated excreta. They also have a lower risk judgment for poultry manure and cow dung.

Regarding benefits, we observe a higher benefit judgment by SHFs for safe practices and technologies. 
Table 3. Difference in risk and benefit judgment between smallholder farmers (SHFs) and traders (Ts).

\begin{tabular}{|c|c|c|c|c|c|c|c|}
\hline \multicolumn{4}{|c|}{ SHFs and Ts: Risks } & \multicolumn{4}{|c|}{ SHFs and Ts: Benefits } \\
\hline Items & $\begin{array}{c}\text { SHFs } \\
(n=103)\end{array}$ & $\begin{array}{c}\text { Ts } \\
(\mathrm{n}=29)\end{array}$ & $\mathrm{SL}$ & Items & $\begin{array}{c}\text { SHFs } \\
(n=101)\end{array}$ & $\begin{array}{c}\text { Ts } \\
(\mathrm{n}=30)\end{array}$ & SL \\
\hline $\begin{array}{l}\text { Fertilization of leafy } \\
\text { vegetables w/treated } \\
\text { faeces }\end{array}$ & 0.86 & -0.77 & $* * *$ & Composting of faeces & 0.89 & -0.68 & *** \\
\hline Traditional pit latrine & 0.38 & -0.95 & $* * *$ & Biogas toilet & 0.48 & -0.56 & * \\
\hline $\begin{array}{l}\text { Eating raw crops } \\
\text { fertilized w/human } \\
\text { excreta }\end{array}$ & 0.35 & 1.14 & $*$ & Storage of human faeces & 0.45 & -0.78 & *** \\
\hline $\begin{array}{l}\text { Weeding farm fertilized } \\
\text { w/untreated faeces/ } \\
\text { urine }\end{array}$ & 0.33 & 1.14 & $* * *$ & $\begin{array}{l}\text { Application of treated } \\
\text { faeces to farm }\end{array}$ & 0.01 & 0.97 & $*$ \\
\hline Bucket toilet & 0.31 & 1.16 & $* * *$ & $\begin{array}{c}\text { Manual transportation of } \\
\text { untreated faeces }\end{array}$ & -0.99 & -0.72 & $*$ \\
\hline Arborloo & 0.08 & 0.91 & * & $\begin{array}{l}\text { Fertilization of leafy } \\
\text { vegetables w/treated } \\
\text { faeces }\end{array}$ & -0.99 & -0.19 & *** \\
\hline $\begin{array}{l}\text { Fertilization of } \\
\text { leguminous plants } \\
\text { w/human excreta }\end{array}$ & -0.17 & 0.94 & $*$ & $\begin{array}{l}\text { Fertilization of leafy } \\
\text { vegetables } \mathrm{w} / \\
\text { untreated faeces }\end{array}$ & -1.03 & -0.72 & $*$ \\
\hline Flush toilet & -0.32 & -0.88 & $*$ & Open defecation & -1.05 & -0.81 & $* *$ \\
\hline $\begin{array}{l}\text { Harvesting crops } \\
\text { fertilized with } \\
\text { untreated excreta }\end{array}$ & -0.42 & 0.98 & $* * *$ & $\begin{array}{l}\text { Application of untreated } \\
\text { faeces to farm }\end{array}$ & -1.05 & -0.78 & $*$ \\
\hline $\begin{array}{l}\text { Manual transportation } \\
\text { of treated faeces }\end{array}$ & -0.44 & 0.95 & ** & & & & \\
\hline $\begin{array}{l}\text { Storage of human } \\
\text { faeces }\end{array}$ & -0.46 & 0.93 & $*$ & & & & \\
\hline $\begin{array}{l}\text { Using poultry manure as } \\
\text { fertilizer }\end{array}$ & -0.48 & -0.98 & $* * *$ & & & & \\
\hline $\begin{array}{l}\text { Application of treated } \\
\text { faeces to farm }\end{array}$ & -0.57 & -0.87 & $* *$ & & & & \\
\hline Cleaning toilet & -0.59 & -1.07 & $* * *$ & & & & \\
\hline Storage of human urine & -0.59 & 0.50 & $*$ & & & & \\
\hline $\begin{array}{l}\text { Mechanized } \\
\text { transportation of } \\
\text { urine }\end{array}$ & -0.59 & -0.95 & ** & & & & \\
\hline $\begin{array}{l}\text { Using cow dung as } \\
\text { fertilizer }\end{array}$ & -0.65 & -0.99 & $* *$ & & & & \\
\hline
\end{tabular}

Values in this table are standardized medians. The Wilcoxon-Mann-Whitney Median Test is used for significance testing between groups or categories of respondents.

$\mathrm{SL}=$ Significance level: ${ }^{*} p<.01,{ }^{* *} p<.001,{ }^{* * *} p<.0001$.

Table 4 shows the significant differences between the risk and benefit judgments of Ts and EHSs. The risk judgment of EHSs is significantly higher for unsafe practices such as open defecation and manual transportation of untreated faeces. Cleaning toilets is judged higher in risk by EHSs. Fertilization of leafy vegetables with treated faeces is judged higher in risk by EHSs. On the other hand, fertilization of leguminous plants and tuber crops with human excreta are judged higher in risk by Ts. Also, Ts have a lower risk judgment for cow dung and poultry manure.

The benefit judgment of EHSs is lower for unsafe practice such as fertilization of leafy vegetables with untreated faeces, manual transportation of untreated faeces, open defecation, manual transportation of urine, and eating raw crops fertilized with human excreta. Even fertilization of leafy vegetables with treated faeces is judged lower in benefit by EHSs. 
Table 4. Difference in risk and benefit judgment between traders (Ts) and environmental health students (EHSs).

\begin{tabular}{|c|c|c|c|c|c|c|c|}
\hline \multicolumn{4}{|c|}{ Ts and EHSs: Risks } & \multicolumn{4}{|c|}{ Ts and EHSs: Benefits } \\
\hline Items & $\begin{array}{c}\text { Ts } \\
(n=29)\end{array}$ & $\begin{array}{c}\text { EHSs } \\
(n=57)\end{array}$ & $\mathrm{SL}$ & Items & $\begin{array}{c}\text { Ts } \\
(\mathrm{n}=30)\end{array}$ & $\begin{array}{c}\text { EHSs } \\
(\mathrm{n}=88)\end{array}$ & SL \\
\hline Open defecation & 1.07 & 1.62 & $* * *$ & $\begin{array}{l}\text { Urine diversion dry toilet } \\
\text { (UDDT) }\end{array}$ & 1.01 & 0.42 & * \\
\hline $\begin{array}{l}\text { Fertilization of leafy } \\
\text { vegetables w/ } \\
\text { untreated faeces }\end{array}$ & 1.03 & 1.26 & * & $\begin{array}{l}\text { Fertilization of leafy } \\
\text { vegetables w/treated } \\
\text { faeces }\end{array}$ & -0.19 & -0.92 & *** \\
\hline $\begin{array}{l}\text { Manual transportation } \\
\text { of untreated faeces }\end{array}$ & 0.96 & 1.48 & $* * *$ & Biogas toilet & -0.56 & 0.67 & $* *$ \\
\hline $\begin{array}{l}\text { Application of faecal } \\
\text { sludge to farm }\end{array}$ & 0.94 & 1.22 & * & Using DAP fertilizer & -0.61 & 0.18 & *** \\
\hline $\begin{array}{l}\text { Fertilization of } \\
\text { leguminous plants } \\
\text { w/human excreta }\end{array}$ & 0.94 & -0.24 & ** & $\begin{array}{l}\text { Manual transportation of } \\
\text { urine }\end{array}$ & -0.70 & -1.09 & *** \\
\hline $\begin{array}{l}\text { Fertilization of tuber } \\
\text { crops with excreta }\end{array}$ & 0.83 & -0.23 & ** & $\begin{array}{l}\text { Manual transportation of } \\
\text { untreated faeces }\end{array}$ & -0.72 & -1.15 & *** \\
\hline $\begin{array}{l}\text { Fertilization of leafy } \\
\text { vegetables w/treated } \\
\text { faeces }\end{array}$ & -0.77 & 0.83 & $* * *$ & $\begin{array}{l}\text { Fertilization of leafy } \\
\text { vegetables w/ } \\
\text { untreated faeces }\end{array}$ & -0.72 & -1.09 & *** \\
\hline $\begin{array}{l}\text { Application of treated } \\
\text { faeces to farm }\end{array}$ & -0.87 & -0.58 & ** & $\begin{array}{l}\text { Eating raw crops fertilized } \\
\text { w/human excreta }\end{array}$ & -0.72 & -1.00 & $*$ \\
\hline Traditional pit latrine & -0.95 & -0.29 & ** & Open defecation & -0.81 & -1.20 & *** \\
\hline $\begin{array}{l}\text { Using poultry manure as } \\
\text { fertilizer }\end{array}$ & -0.98 & -0.78 & * & Bucket toilet & -0.83 & -0.34 & * \\
\hline $\begin{array}{l}\text { Using cow dung as } \\
\text { fertilizer }\end{array}$ & -0.99 & -0.82 & * & & & & \\
\hline Cleaning toilet & -1.07 & -0.80 & $* * *$ & & & & \\
\hline
\end{tabular}

Values in this table are standardized medians. The Wilcoxon-Mann-Whitney Median Test is used for significance testing between groups or categories of respondents.

$\mathrm{SL}=$ Significance level: ${ }^{*} p<.01,{ }^{* *} p<.001,{ }^{* * *} p<.0001$.

\section{Correlation}

We correlated risk and benefit across 45 standardized medians for EHSs, SHFs, and Ts as further demonstration of the inverse relationship of risk and benefit judgments. This relationship holds for all the groups. The correlations were -0.90 for EHSs; -0.77 for SHFs; and -0.70 for Ts. These are all significant at $p<.0001$.

\section{Discussion}

The finding reveals an inverse relationship between risk and benefit judgments. This relationship holds for the three groups with different backgrounds and different settings (i.e., EHSs, SHFs, and Ts). Practices or technologies that were judged high in risk were also judged low in benefits, and those that were judged high in benefits were judged low in risk. As expected, unsafe practices and technologies involving direct contact with excreta were judged high in risk and low in benefit, and conversely, safe practices and technologies involving treated excreta were judged high in benefit and low in risk, which is an indication of pathogen sensitivity. The risk and benefit correlations between the three groups are strong and all significant at $p<.0001$. This finding is in line with other studies that have shown 
that affect plays a key role in risk perception and that people use affect heuristic in making judgments and decisions (Zajonc 1980; Alhakami and Slovic 1994; Finucane et al. 2000).

There are significant differences in judgment between the groups of participants for some items as shown in Tables 2, 3, and 4. EHSs exhibit higher sensitivity than SHFs for some unsafe practices and technologies, namely: open defecation, fertilization of leafy vegetables with untreated faeces, manual transportation of untreated faeces, application of faecal sludge to farm, weeding farm fertilized with untreated faeces and urine. Safe practices such as applying treated faeces to farm and fertilization of flowers with excreta are considered much beneficial by EHSs than by SHFs. Regarding the judgments of SHFs and Ts, SHFs show higher sensitivity for unsafe practices. Even practices such as the use of treated faeces on leafy vegetables and cleaning toilet are considered highly risky by SHFs than by Ts. EHSs exhibit higher risk sensitivity than Ts for certain unsafe practices. Even cleaning toilet and the use of treated faeces to fertilize leafy vegetables is judged higher in risk by EHSs than by Ts.

There is a preference for cow manure mainly among Ts and EHSs. SHFs show a slight preference for human manure over cow manure. This is possibly due to the fact that the use of UDDTs and application of human excreta to farm are common among this group of participants in the rural communities where we performed the investigation. Poultry manure is preferred by Ts and EHSs. We also see a preference for chemical agricultural inputs especially among EHSs. Fertilization of non-fruit trees with human excreta is preferred by EHSs and SHFs. Fertilization of flowers with human excreta is preferred only by EHSs. Generally, UDDTs and practices involving safe collection, treatment and use of human excreta are perceived to have low risk and high benefits. In addition, practices such as fertilization of leafy vegetables with untreated faeces and eating raw crops fertilized with human excreta are judged high in risks and low in benefits.

Judging from above, EHSs exhibit higher sensitivity for unsafe practices than the other two groups of respondents. The differences in judgment between the groups could be attributed to factors such as risk tolerance, practical experience, and knowledge of risk management. Students may have the theoretical background in risk management but have low risk tolerance and perhaps no practical experience. SHFs, however, perhaps understand risk differently and have a higher tolerance for it as we have also seen from cases in Vietnam, China and Ghana where some farmers are not very particular about safety. Also, practical experience in using human excreta plays a major role.

Worth highlighting are two common practices that constitute major challenges in sanitation service delivery and hygiene promotion. One of them is handwashing with soap after using the toilet and handling human excreta, which is judged highly beneficial by participants. The other is open defecation, which is judged highly risky. However, in reality, proper handwashing behavior remains difficult to instill and hard to sustain, and open defecation habits are hard to eradicate among some individuals and within certain communities. High rates of compliance are unlikely where the targeted individuals lack material and cognitive resources needed to comply even if they are willing to do so (Weaver 2014). For instance albeit preference for handwashing with soap, compliance is difficult to achieve when basic resources such as water and soap are inadequate or lacking. Also, people defecating in the open may simply be doing so due to lack of toilets or may lack the ability to make reasoned decisions in their own best interest and that of the entire community. In addition, where there is little or no compliance with recommended safety guidelines, negative framing has 
the potential to motivate preventive action and change behavior (Block and Keller 1995). Block and Keller (1995) posit that only when an individual feels that the recommended behavior is likely to lead to the desired outcome will adoption of recommendations occur.

The inverse relationship between perceived risk and benefit that we demonstrated is relevant in explaining the issues this article addresses, namely: resistance to the use of human excreta as fertilizer in agriculture in most communities; and the prevailing unsafe use of human excreta in agriculture in some communities. First, individuals with high risk and low benefit judgment for excreta related practices would eschew them or emphasize strict standards. Second, individuals with a high benefit and low risk judgment would engage in excreta management practices regardless of safety precautions as highlighted in the case of Vietnam (Phuc et al. 2006; Pham-Duc et al. 2014; Mackie Jensen et al. 2008) and Ghana (Cofie et al. 2005).

In analyzing the perception of risks, aggregate data are taken across all participants. There are, however, individual differences in risk perception that are neglected by using aggregated data (Siegrist et al. 2005). In addition, the factors responsible for the observed cross-cultural differences between individuals are not easily discernible (Boholm 1998). Furthermore, the insights from this study cannot be generalized given the type of sampling method we employed. Most psychometric studies employ non-probabilistic method wherein statistical data is gathered from a population. This method differs from random sampling in that rather than gathering an array of data from the entire population as is done in random sampling, data is collected from a cross section of the population. Hence data collected in this manner may hardly be considered representative of an entire population or setting. Generalization from such studies may thus be misleading. However, the type of sampling used in psychometric studies is appropriate for studying certain trends within particular samples without necessarily attempting to make generalizations. If one must make generalizations of some kind from such studies, replication of results across numerous smaller studies within the same setting and population of interest as well as during different periods is important. Thus the fact that we replicated the inverse relationship between risk and benefit judgments with three groups of individuals from different backgrounds (EHSs, SHFs, and Ts) and settings (rural and urban Rwanda and Uganda) is an interesting finding and an important contribution to the body of literature on risk perception and human behavior.

\section{Conclusion}

We investigated the role of affect in risk and benefit judgment of excreta as fertilizer in relation to other types of agricultural inputs. Having demonstrated the inverse relationship between risk and benefit judgments which is consistent with Alhakami and Slovic (1994) and Finucane et al. (2000), we conclude that the evaluation mechanism in risk perception of human excreta related practices and the use of human excreta as fertilizer in agriculture depends to an extent on feelings or affect. This finding is consistent with other studies showing that affect plays a key role in risk perception, judgment, and decision-making (Zajonc 1980; Damasio et al. 1991; Shafir et al. 1993; Damasio 1994; Slovic 2000a,b, 2010; Finucane et al. 2000, 2003; Svenson 2003).

We have also shown that human excreta generally evoke repugnance because they are marked with a negative image in people's minds, which is part of the instinctive mechanism 
deterring people from getting in contact with substances or objects that can potentially contaminate and cause harm. In addition, we posit that negative emotional reactions towards excreta, faeces in particular are so strong that they persist even after the substances have been properly treated and rendered innocuous. This plays a major role in influencing judgment and decision-making regarding the productive use of excreta. Moreover, "uncertainty" and "unknown" regarding exposure especially to pathogens and contaminants in excreta and the potential health threats exacerbate risk perception toward them. A combination of pathogen sensitivity and risk perception engender "dread," which fuels resistance to the use of excreta as fertilizer in agriculture. As we have also shown, this resistance is, however, not an issue among some individuals and within certain communities where unsafe use of untreated excreta prevails with concomitant public health problems.

Furthermore, our finding reveals that SHFs in communities where UDDTs have been introduced and where excreta are used as fertilizer, exhibit a slight preference for human manure. We have also shown that animal manure, cow dung in particular also has high potential to contaminate and cause harm even though they are commonly used and, as the finding of this study reveals, are preferred by Ts and EHSs.

To get people to safely use excreta in agriculture requires an understanding of the risk and benefit tradeoffs people make, the reasons why they engage in such practices, and the extent to which they understand the risks involved. This is important for risk communication as it enables risk information to be effectively targeted to specific groups of individuals when addressing specific gaps connected with risky or dreaded practices or technologies. Renn (2008) emphasizes that risk information must explicitly address aspects of potential benefits and social needs of the people it serves for it to correspond with their expressed and revealed preferences.

The novel insights from this study are relevant for sanitation, health, hygiene, and agriculture policies and practices in general and specifically for risk communication and risk management. This is because they show that individuals do not rely only on risk management information they receive regarding human excreta and related risks but also depend to an extent on their personal feelings about these substances in making judgments and decisions regarding the purpose for using excreta and the level of exposure they can tolerate when using excreta for productive purposes. This points to the fact that risk managers and assessors should take cognizance of affective processes or mechanisms in their interventions. Also, as we have shown in this investigation, risk means different things to different people, which requires that risk communication programs or campaigns should be tailored for different groups with this in mind.

We have shown that sanitation and hygiene practices in general and productive use of human excreta in particular are surrounded with numerous aspects that have their answers in psychology. Giving the exploratory nature of this investigation, we have extended the risk and benefit paradigm into a different culture and domain, where we find it highly relevant in providing significant insights for understanding human behavior, judgment, and decision-making regarding human excreta and their use for productive purposes.

\section{Acknowledgments}

C. K. Mertz and Paul Slovic of Decision Research (DR) in Eugene, Oregon (USA) were instrumental in the realization of this research. We thank Network for Water and Sanitation (NETWAS) Uganda and the former Kigali Health Institute (KHI), Rwanda for facilitation in the field. 


\section{Funding}

This research was initiated thanks to grants from the Royal Swedish Academy of Agriculture and Forestry (Kungl. Skogs och Lantbruksakademien) (H10-0233-ADA-01) and from Stiftelsen Lars Hiertas minne (FO2010-0322 and FO2011-0501). Travel grants were also provided by Stiftelsen Futura. Some research activities were performed within a Stockholm Environment Institute (SEI) Sida programme support project. This research is now incorporated within the Vetenskapsrådet U-forsk project (2013-6364).

\section{References}

Alhakami A and Slovic P. 1994. A psychological study of the inverse relationship between perceived risk and benefit. Risk Analy 14(6):1085-96. doi:10.1111/j.1539-6924.1994.tb00080.x

Bickerstaff K. 2004. Risk perception research: Socio-cultural perspectives on the public experience of air pollution. Environ Inter 30(6):827-40

Block L and Keller A. 1995. When to accentuate the negative: The effects of perceived efficacy and message framing on intentions to perform a health-related behavior. J Market Res, Amer Market Res 32(2):192-203

Boholm A. 1998. Comparative studies of risk perception: A review of twenty years of research. J Risk Res 1:135-63

Bostrom A. 1997. Risk perceptions: "Experts" vs "lay people." Duke Environmental Law and Policy Forum, September 8(1):101-13

Callaghan P, Moloney G, and Blair D. 2012. Contagion in the representational field of water recycling: Informing new environment practice through social representation theory. J Comm Appl Soc Psychol 22:20-37

Cofie OO, Kranjac-Berisavljevic G, and Drechsel P. 2005. The use of human waste for peri-urban agriculture in northern Ghana. Renewable Agric Food Sys 20(2):73-80

Curtis V. 2013. Don't Look, Don't Touch, Don't Eat: The Science Behind Revulsion. The University of Chicago Press, Chicago, IL, USA

Damasio A. 1994. Descartes' Error: Emotion, Reason, and the Human Brain. Grosset/Putnam, Avon, New York, NY, USA

Damasio A, Tranel D, and Damasio H. 1991. Somatic markers and the guidance of behaviour: Theory and preliminary testing. In: Levin HS, Eisenberg HM, and Benton AL (eds), Frontal Lobe Function and Dysfunction, pp 217-28. Oxford University Press, New York, NY, USA

De Barra M. 2011. Attraction and aversion: Pathogen avoidance strategies in the UK and Bangladesh. PhD diss., London School of Hygiene and Tropical Medicine, London, UK

Douglas M and Wildavsky A. 1982. Risk and culture: An essay on the selection of technological and environmental dangers. University of California Press, Berkeley, CA, USA

Ekane N, Kjellén M, Noel S, et al. 2012. Sanitation and hygiene: Policy, stated beliefs and actual practice. A case study in the Burera district, Rwanda. Stockholm Environment Institute (SEI), Working Paper 2012-07. Available at http://www.sei-international.org/mediamanager/documents/Publica tions/SEI-WorkingPaper-Ekane-SanitationHygieneRwanda.pdf

Eiser JR, Bostrom A, Burton I, et al. 2012. Risk interpretation and action: A conceptual framework for responses to natural hazards. Inter J Disast Risk Reduct 1(2012):5-16

Epstein S. 1994. Integration of the cognitive and psychodynamic unconscious. Am Psychol 49(8):709-24. doi:10.1037/0003-066x.49.8.709

Esrey SA, Feachem RG, and Hughes JM. 1985. Interventions for the control of diarrhoeal diseases among young children: Improving water supplies and excreta disposal facilities. Bull WHO 63(4):757-72

Esrey S, Gough J, Rapaport D, et al. 1998. Ecological Sanitation. Sida, Stockholm, Sweden

Esrey SA and Habicht JP. 1986. Epidemiologic evidence for health benefits from improved water and sanitation in developing countries. Epidemiol Rev 8:117-28 
Esrey SA, Potash JB, Roberts L, et al. 1991. Effects of improved water supply and sanitation on ascariasis, diarrhoea, dracunculiasis, hookworm infection, schistosomiasis, and trachoma. Bull WHO 69(5):609-21

Feachem RG, Bradley DJ, Garelick H, et al. 1983. Sanitation and disease: Health aspects of excreta and wastewater management. World Bank Studies in Water Supply and Sanitation 3, Wiley, Chichester, UK

Finucane M, Alhakami A, Slovic P, et al. 2000. The affect heuristic in judgment of risks and benefits. J Behav Dec Mak 13:1-17

Finucane M, Peters E, and Slovic P. 2003. Judgment and decision making: The dance of affect and reason. In: Schneider S and Shanteau J (eds), Emerging Perspectives on Judgment and Decision Research, pp 284-326. Cambridge Series on Judgment and Decision Making. Cambridge University Press, Cambridge, UK

Fischhof B, Slovic P, Lichtenstein S, et al. 1978. How safe is safe enough? A psychometric study of attitudes toward technological risks and benefits. Pol Sci 9:127-52

Frewer L. 2004. The public and effective risk communication. Toxicol Lett 149(1-3):391-7

Heinonen-Tanski $\mathrm{H}$ and van Wijk-Sijbesma C. 2005. Human excreta for plant production. Biores Technol 96:403-11

Höglund C, Stenström T, Vinnerås B, et al. 1999. Chemical and microbiological composition of human urine. In: Proc. Int. Civil and Environmental Eng. Conference, II:105-112. Bangkok, Thailand, November 6-12

Jones P and Martin M. 2003. A review of the literature on the occurrence and survival of pathogens of animal and humans in green compost. Research Report. The Waste and Resources Action Programme (WRAP), UK

Kahneman D. 2011. Thinking, Fast and Slow. Farrar, Straus and Giroux, New York, NY, USA

Karg H and Drechsel P. 2011. Motivating behavior change to reduce pathogenic risk where unsafe water is used for irrigation. Water Inter 36(4):476-90

Kärrman E, Jönsson H, Sonnesson U, et al. 1999. System analysis of wastewater and solid organic waste-Conventional treatment compared to licit composting, urine separation and irrigation to energy forest. In: Proceedings of the International Civil and Environmental Engineering Conference, pp V27-V36. Bangkok, Thailand, November 8-12

King FH. 1927. Farmers of Forty Centuries. Jonathan Cape, London, UK (Reprinted in 1972 by Rodale Press)

Knudsen L, Phuc P, Hiep N, et al. 2008. The fear of awful smell: Risk perceptions among farmers in Vietnam using wastewater and human excreta in agriculture. South East Asian J Med Publ Health 39(2):341-52

Köpke U, Krämer J, and Leifert C. 2007. Pre-harvest strategies to ensure microbiological safety of fruit and vegetables from manure-based production systems. In: Cooper J, Niggli U, and Leifert C (eds), Handbook of Organic Food Safety and Quality, pp 413-29. Woodhead Publishing, Cambridge, UK

Kosek M, Bern C, and Guerrant RL. 2003. The magnitude of the global burden of diarrhoeal disease from studies published 1992-2000. Bull WHO 81:197-204

Mackie Jensen PK, Pham-Duc P, Knudsen LG, et al. 2008. Hygiene versus fertilizer: The use of human excreta in agriculture-A Vietnamese example. Int J Hyg Environ Health 211:432-9

Magid J, Eilersenb AM, Wrisberga S, et al. 2006. Possibilities and barriers for recirculation of nutrients and organic matter from urban to rural areas: A technical theoretical framework applied to the medium-sized town Hillerød, Denmark. Ecolog Eng 28:44-54

Marris C, Langford I, and O'Riordan T. 1998. A quantitative test of the cultural theory of risk perceptions: Comparison with the psychometric paradigm. Risk Analy 18(5):635-47

Meng B, Liu M, Liufu HY, et al. 2013. Risk perceptions combining spatial multi-criteria analysis in land-use type of Huainan city. Saf Sci 51(1):361-73

Morella E, Foster V, and Ghosh Banerjee S. 2008. Climbing the ladder: The state of sanitation in subSaharan Africa. Background Paper 13 (Phase 1); Africa Infrastructure Country Diagnostic, 9

Murphy ST and Zajonc RB. 1993. Affect, cognition, and awareness: Affective priming with optimal and suboptimal stimulus exposures. J Personal Soc Psychol 64:723-39

Pell A. 1997. Manure and microbes: Public and animal health problem? J Dairy Sci 80:2673-81 
Peters E, McCaul K, Stefanek M, et al. 2006. A Heuristics approach to understanding cancer risk perception: Contributions from judgment and decision-making research. Annals Behav Med 31(1):45-52. Available at http://faculty.psy.ohio-state.edu/peters/lab/pubs/publications/2006_PetersMcCaulNelson Stefanek_AnnalsBehMed2564.pdf

Pham-Duc P, Nguyen-Viet H, Hattendorf J, et al. 2011. Risk factors for Entamoeba histolytica infection in an agricultural community in Hanam province, Vietnam. Parasites and Vectors 4:102

Pham-Duc P, Nguyen-Viet H, Hattendorf J, et al. 2014. Diarrhoeal diseases among adult population in an agricultural community in Hanam province, Vietnam, with high wastewater and excreta re-use. BMC Public Health 14:978

Phuc PD, Konradsen F, Phuong PT, et al. 2006. Practice of using human excreta as fertilizer and implications for health in Nghe An Province, Vietnam. SE Asian J Trop Med Publ Health 37(1):222-9

Polprasert C. 2007. Organic Waste Recycling: Technology and Management. 3rd edit. IWA Publishing, London, UK

Prüss A, Kay D, Fewtrell L, et al. 2002. Estimating the burden of disease from water, sanitation and hygiene at a global level. Environ Health Perspect 110(5):537-42

Renn O. 2008. Risk communication: Insights and requirements for designing successful communication programs on health and environmental hazards. In: Heath RL and Dan O'Hair H (eds), Handbook of Risk and Crisis Communication, pp 81-99. Taylor and Francis, London, UK

Renn O and Rohrmann B. 2000. Cross-Cultural Risk Perception: A Survey of Empirical Studies. Kluwer, Dordrecht, the Netherlands and Boston, Massachusetts, USA

Rockefeller A. 1998. Civilization and sludge: Notes on the history of the management of human excreta. Current World Leaders 39(6). Available at: https://www.organicconsumers.org/news/civili zation-sludge-notes-history-management-human-excreta

Rosemarin A, Ekane N, Caldwell I, et al. 2008. Pathways for Sustainable Sanitation. IWA Publishing, Geneva, Switzerland

Rozin P, Haddad B, Nemeroff C, et al. 2015. Psychological aspects of the rejection of recycled water: Contamination, purification and disgust. Judg Dec Mak 10(1):50-63

Schouw N, Danteravanich S, Mosbaek H, et al. 2002. Composition of human excreta-A case study from Southern Thailand. Sci Tot Environ J 286(1-3):155-66

SCU (Science Communication Unit), University of the West of England, Bristol (Public Risk Perception and Environmental Policy). 2014. Science for Environment Policy Future Brief. Report produced for the European Commission DG Environment, September 2014. Available at http://ec. europa.eu/science-environment-policy

Siegrist M, Keller C, and Kiers H. 2005. A new look at the psychometric paradigm of perception of hazards. Risk Analy 25(1):211-22

Sjöberg L, Moen BE, and Rundmo T. 2004. Explaining risk perception: An evaluation of the psychometric paradigm in risk perception research. Rotunde publikasjoner 84:33

Slovic P. 1992. Perception of risk: Reflections on the psychometric paradigm. In: Krimsky S and Golding D (eds), Social Theory of Risk, pp 117-152. Praeger, London, UK

Slovic P (ed). 2000a. The Perception of Risk. Risk, Society and Policy Series. Earthscan, London, UK

Slovic P. 2000b. Rational actors and rational fools: The influence of affect on judgment and decisionmaking. Roger Williams U Law Rev 6(1):163-212

Slovic P (ed). 2010. The Feeling of Risk. New Perspectives on Risk Perception. Earthscan, New York, NY, USA

Slovic P, Finucane M, Peters E, et al. 2002a. The affect heuristic. In: Gilovich T, Griffin D, and Kahneman D (eds), Heuristics and Biases: The Psychology of Intuitive Judgment, pp 397-420. Cambridge University Press, New York, NY, USA

Slovic P, Finucane M, Peters E, et al. 2002b. Rational actors or rational fools: Implications of the affect heuristic for behavioral economics. J Socio-Econom 31:329-42

Slovic P, Finucane M, Peters E, et al. 2004. Risk as analysis and risk as feelings: Some thoughts about affect, reason, risk, and rationality. Risk Analys 24:1-12

Slovic P, Fischhoff B, and Lichetenstein S. 1985. Characterizing perceived risk. In: Kates W, Hohenemser C, and Kasperson J (eds), Perilous Progress: Managing the Hazards of Technology, pp 91125. Westview Press, Boulder, CO, USA 
Smith E, Burkle Jr F, and Archer F. 2011. Fear, familiarity, and the perception of risk: A quantitative analysis of disaster-specific concerns of paramedics. Dis Med Publ Health Prep. AMA 5(1):46-53

Sparrow M. 2008. The Character of Harms: Operational Challenges in Control. Cambridge University Press, Cambridge, UK

Svenson O. 2003. Values, affect, and processes in human decision making: A differentiation and consolidation theory perspective. In: Schneider S and Shanteau J (eds), Emerging Perspectives on Judgment and Decision Research, pp 284-326. Cambridge Series on Judgment and Decision Making. Cambridge University Press, Cambridge, UK

Thompson M, Ellis R, and Wildavsky A. 1990. Cultural Theory. Westview Press, Boulder, CO, USA

Tybur J, Kurzban R, Lieberman D, et al. 2013. Disgust: Evolved function and structure. Psychol Rev 120(1):65-84

Van der Hoek W, Konradsen F, Cam PD, et al. 2003. Current status of soil-transmitted helminths in Vietnam. SE Asian J Trop Med Publ Health 34:1-11

Verle P, Kongs A, De V, et al. 2003. Prevalence of intestinal parasitic infections in Northern Vietnam. Trop Med Inter Health 8:961-4

Viau E, Bibby K, Paez-Rubio T, et al. 2011. Toward a consensus view on the infectious risks associated with land application of sewage sludge. Environ Sci Technol 45:5459-69

WDR. 2015. Mind, Society, and Behavior. World Development Report 2015. World Bank Group Flagship Report. International Bank for Reconstruction and Development. The World Bank. Available at http://www.worldbank.org/content/dam/Worldbank/Publications/WDR/WDR\%202015/WDR2015-Full-Report.pdf

Weaver K. 2014. Compliance regimes and barriers to behavioral change. Governance: Inter J Policy, Admin Inst 27(2):243-65

WHO. 1989. Guidelines for the Safe Use of Wastewater and Excreta in Agriculture and Aquaculture: Measures for Public Health Protection. World Health Organization, Geneva, Switzerland

WHO. 2006a. Guidelines for the Safe Use of Wastewater, Excreta and Greywater: Wastewater Use in Agriculture. Volume II. World Health Organization, Geneva, Switzerland

WHO. 2006b. Guidelines for the Safe Use of Wastewater, Excreta and Greywater: Excreta and Greywater Use in Agriculture. Volume IV. World Health Organization, Geneva, Switzerland

WSP. 2012. Africa: Economics of Sanitation Initiative. Water and Sanitation Programme. Available at http://www.wsp.org/content/africa-economic-impacts-sanitation

Yamano T and Arai A. 2010. Fertilizer policies, price, and application in East Africa. GRIPS Discussion Paper 10-GRIPS Discussion Paper, 10-24

Zajonc R. 1980. Feeling and thinking: Preferences need no inferences. Amer Psychol 35:151-75

Zhang S. 2011. Air quality and community health impact of animal manure management. Evidence review. National Collaborating Centre for Environmental Health, Canada 


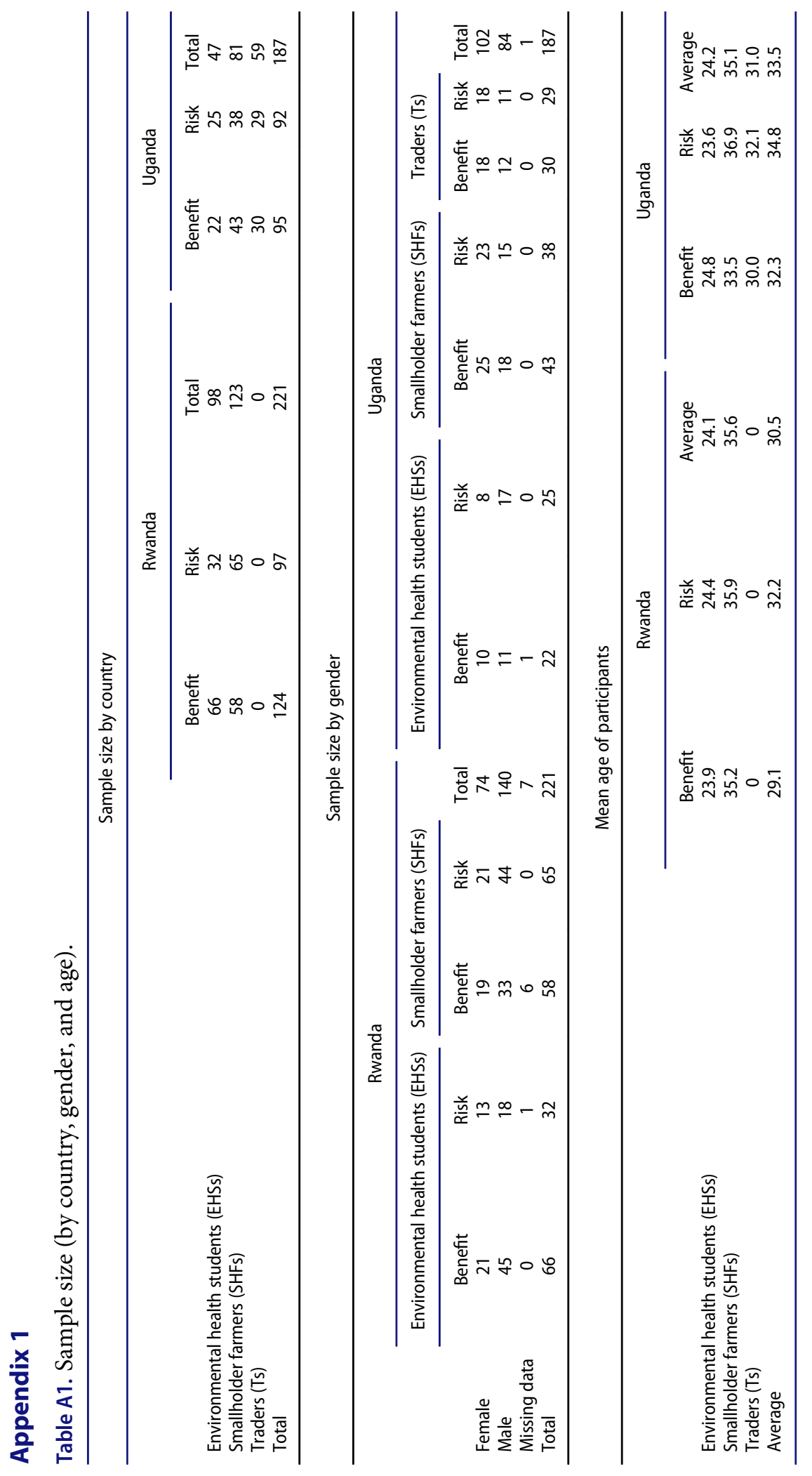




\section{Appendix 2}

\section{Survey instrument}

\section{SURVEY: A PSYCHOMETRIC SURVEY OF RISK AND BENEFIT PERCEPTION}

\section{A. BENEFIT PERCEPTION SURVEY}

This is a difficult but not impossible task. It is similar to the task you face when you make judgments and decisions on different alternatives. You may not have all the relevant information, yet some judgment must be made.

Perceived Benefits (assess gross benefits during one year, i.e., after cost and risk are subtracted). People judging perceived benefits will not judge perceived risks (Table A2).

Table A2. Perceived benefits.

\begin{tabular}{ll}
\hline & $\begin{array}{l}\text { Perceived benefits (Assign numerical benefit } \\
\text { values-i.e., } 10 \text { for least beneficial and } 300 \text { for } \\
\text { most beneficial) }\end{array}$
\end{tabular}

\section{TECHNOLOGY}

1 Urine diversion dry toilet (UDDT)

2 Bucket toilet

3 Arborloo (fill shallow pit and cover)

4 Biogas toilet

5 Traditional pit latrine

6 Ventilated improved pit latrine (VIP)

7 Flush toilet

ACTIVITY/PRACTICE

8 Open defecation

Hygiene behaviour/practice

9 Cleaning toilet

10 Washing hands with soap after using toilet and handling human excreta

Collection of human excreta

11 Manually emptying pit toilet and septic tank (faecal sludge)

12 Separate collection of human faeces and urine

Treatment of human excreta

13 Storage of human faeces

14 Storage of human urine

15 Composting human faeces

Transportation of human excreta

16 Manual transportation of human untreated faeces

17 Manual transportation of treated human faeces

18 Mechanized transportation of untreated human faeces

19 Mechanized transportation of treated human faeces

20 Manual transportation of human urine

21 Mechanized transportation of human urine

Application of human excreta to farm

22 Application of untreated faecal sludge to farm

23 Application of treated human faeces to farm

24 Application of human urine to farm

Type of crop

25 Fertilization of leafy vegetables with untreated human faeces

26 Fertilization of leafy vegetables with treated human faeces

27 Fertilization of leafy vegetables with human urine

28 Fertilization of tuber crops with human excreta

29 Fertilization of fruit trees with human excreta

30 Fertilization of leguminous plants, e.g., beans, peas with human excreta

31 Fertilization of flowers with human excreta

32 Fertilization of non-fruit trees with human excreta

Farming practice

33 Weeding farm fertilized with untreated human excreta 
Table A2. (Continued)

\begin{tabular}{ll}
\hline Items & $\begin{array}{l}\text { Perceived benefits (Assign numerical benefit } \\
\text { values-i.e., } 10 \text { for least beneficial and } 300 \text { for } \\
\text { most beneficial) }\end{array}$ \\
\hline 34 Harvesting of crops fertilized with untreated human excreta \\
35 Harvesting of crops fertilized with treated human excreta \\
Handling and consumption of crop fertilized with human excreta \\
36 Selling crops fertilized with human excreta \\
37 Washing crops fertilized with human excreta \\
38 Eating raw crops fertilized with human excreta \\
OTHER ORGANIC INPUTS \\
39 Using human excreta as fertilizer \\
40 Using cow dung as fertilizer \\
41 Using poultry manure as fertilizer \\
42 Using pig manure as fertilizer \\
ARTIFICIAL INPUTS \\
43 Using nitrogen, phosphorus, and potassium (NPK) fertilizer \\
44 Using diammonium phosphate (DAP) fertilizer \\
45 Using Urea fertilizer
\end{tabular}

Same list of items and criteria were used for perceived risk.

1. Carefully study each technology/activity/practice/agricultural input individually and think of the benefits accruing from each item (please see Perceived Benefit Table). Benefits could be: improved health and safety, increased crop yield from sales of agricultural produce, savings, e.g., time saved, money saved, comfort, convenience, etc.

2. Assign numerical benefit values by giving rating of 10 to the least beneficial and scaling the other ratings accordingly (e.g., 10 for least beneficial and 300 for most beneficial).

\section{NOTE}

A beneficial activity affecting few people will have less gross benefit than a beneficial activity affecting many people. Think of the total value to society from each item during one year.

A rating of 12 indicates that the activity is 1.2 times as beneficial as the least beneficial item (i.e., $20 \%$ more beneficial). A rating of 200 for instance means that the activity is 20 times as beneficial as the least beneficial activity, to which 10 was assigned. Do not consider costs of risk associated with the listed technologies/activities/practices/agricultural inputs.

Double check your ratings to make sure that they are consistent. For example, if one technology/activity/practice/agricultural input is rated 50 and a second 100, the second item should seem twice as beneficial as the first. Adjust the numbers until you feel that they are right for you.

\section{QUESTIONNAIRE \\ SURVEY: A PSYCHOMETRIC SURVEY OF RISK AND BENEFIT PERCEPTION B. RISK PERCEPTION SURVEY}

This is a difficult but not impossible task. It is similar to the task you face when you make judgments and decisions on different alternatives. You may not have all the relevant information, yet some judgment must be made.

Perceived Risks (total risk per year to people and NOT risk per hour). People will not judge perceived benefits (Table A3). 
Table A3. Perceived risks.

\begin{tabular}{|c|c|c|}
\hline \multicolumn{2}{|c|}{ Items } & $\begin{array}{l}\text { Perceived risks (Assign numerical risk values- } \\
\text { i.e., } 10 \text { for least risky and } 300 \text { for most risky) }\end{array}$ \\
\hline \multicolumn{3}{|c|}{ TECHNOLOGY } \\
\hline 1 & Urine diversion dry toilet (UDDT) & \\
\hline 2 & Bucket toilet & \\
\hline 3 & Arborloo (fill shallow pit and cover) & \\
\hline 4 & Biogas toilet & \\
\hline 5 & Traditional pit latrine & \\
\hline 6 & Ventilated improved pit latrine (VIP) & \\
\hline 7 & Flush toilet & \\
\hline \multicolumn{3}{|c|}{ ACTIVITY/PRACTICE } \\
\hline \multirow{2}{*}{\multicolumn{3}{|c|}{$\begin{array}{l}8 \quad \text { Open defecation } \\
\text { Hygiene behaviour/practice }\end{array}$}} \\
\hline & & Hygiene behaviour/practice \\
\hline 9 & Cleaning toilet & \\
\hline 10 & Washing hands with soap after using toilet and handling human excreta & \\
\hline \multicolumn{3}{|c|}{ Collection of human excreta } \\
\hline 11 & Manually emptying pit toilet and septic tank (faecal sludge) & \\
\hline 12 & Separate collection of human faeces and urine & \\
\hline \multicolumn{3}{|c|}{ Treatment of human excreta } \\
\hline 13 & Storage of human faeces & \\
\hline 14 & Storage of human urine & \\
\hline 15 & Composting human faeces & \\
\hline \multicolumn{3}{|c|}{ Transportation of human excreta } \\
\hline 16 & Manual transportation of human untreated faeces & \\
\hline 17 & Manual transportation of treated human faeces & \\
\hline 18 & Mechanized transportation of untreated human faeces & \\
\hline 19 & Mechanized transportation of treated human faeces & \\
\hline 20 & Manual transportation of human urine & \\
\hline 21 & Mechanized transportation of human urine & \\
\hline \multicolumn{3}{|c|}{ Application of human excreta to farm } \\
\hline 22 & Application of untreated faecal sludge to farm & \\
\hline 23 & Application of treated human faeces to farm & \\
\hline 24 & Application of human urine to farm & \\
\hline \multicolumn{3}{|c|}{ Type of crop } \\
\hline 25 & Fertilization of leafy vegetables with untreated human faeces & \\
\hline 26 & Fertilization of leafy vegetables with treated human faeces & \\
\hline 27 & Fertilization of leafy vegetables with human urine & \\
\hline 28 & Fertilization of tuber crops with human excreta & \\
\hline 29 & Fertilization of fruit trees with human excreta & \\
\hline 30 & Fertilization of leguminous plants, e.g., beans, peas with human excreta & \\
\hline 31 & Fertilization of flowers with human excreta & \\
\hline 32 & Fertilization of non-fruit trees with human excreta & \\
\hline \multicolumn{3}{|c|}{ Farming practice } \\
\hline 33 & Weeding farm fertilized with untreated human excreta & \\
\hline 34 & Harvesting of crops fertilized with untreated human excreta & \\
\hline 35 & Harvesting of crops fertilized with treated human excreta & \\
\hline \multicolumn{3}{|c|}{ Handling and consumption of crop fertilized with human excreta } \\
\hline 36 & Selling crops fertilized with human excreta & \\
\hline 37 & Washing crops fertilized with human excreta & \\
\hline 38 & Eating raw crops fertilized with human excreta & \\
\hline \multicolumn{3}{|c|}{ OTHER ORGANIC INPUTS } \\
\hline 39 & Using human excreta as fertilizer & \\
\hline 40 & Using cow dung as fertilizer & \\
\hline 41 & Using poultry manure as fertilizer & \\
\hline 42 & Using pig manure as fertilizer & \\
\hline \multicolumn{3}{|c|}{ ARTIFICIAL INPUTS } \\
\hline 43 & Using nitrogen, phosphorus, and potassium (NPK) fertilizer & \\
\hline 44 & Using diammonium phosphate (DAP) fertilizer & \\
\hline 45 & Using Urea fertilizer & \\
\hline
\end{tabular}


1. Carefully study each technology/activity/practice/agricultural input individually and think of the risks accruing from each item (please see Perceived Risks table). Risks could be the exposure of users of technologies, children, workers, farmers, sellers, consumers to disease causing pathogens and other chemical contaminants when dealing with untreated and treated human excreta as well as with other organic agricultural inputs. Risks could also include social stigma associated with certain activities, ground water contamination, etc.

2. Assign numerical risk values by giving rating of 10 to the least risky and scaling the other ratings accordingly (e.g., 10 for least risky and 300 for most risky)

\section{NOTE}

A rating of 12 indicates that the activity is 1.2 times as risky as the least risky item (i.e., $20 \%$ more risky). A rating of 200 for instance means that the activity is 20 times as risky as the least risky activity, to which 10 was assigned. Do not consider costs of risk associated with the listed technologies/activities/practices/agricultural inputs.

\section{Appendix 3}

\section{Data cleaning}

Some participants used the scale very differently from others. Some participants used the upper end of the scale only and others used the lower end. For example, for one person, the lowest rating was 200 (instead of 10). For others, their lowest rating was 10, but their highest rating was only 113. It appears that participants are giving an affective rating or feeling of risk (or benefit) and are having trouble translating their feelings about risk and benefit to a number. Their ratings probably reflect their feelings about the relative relationship between the items and an ordinal ranking of items. Since the number of outliers or out-of-range data was low overall, this data was winsorized. Low outliers (responses 1 to 9) were winsorized to 10 . Responses over 300 were winsorized to 300 . To use the participants' absolute rating could lead to skewed or spurious results. Thus, each person's responses were standardized within their set of 45 responses. The ratings for each participant were standardized around a mean score of 0 with a standard deviation of 1 . 